AS WE SEE IT*

\title{
Gelatinous plankton: irregularities rule the world (sometimes)
}

\author{
F. Boero ${ }^{1, * * * * * *}$, J. Bouillon ${ }^{1}$, C. Gravili ${ }^{1}$, M. P. Miglietta ${ }^{2}$, T. Parsons ${ }^{3}$, S. Piraino ${ }^{1, * * *}$ \\ ${ }^{1}$ DiSTeBA, CoNISMa, Stazione di Biologia Marina, Università del Salento, 73100 Lecce, Italy \\ ${ }^{2}$ Smithsonian Tropical Research Institute, Naos Marine Laboratory, PO Box 0843-03092 Balboa, Panama \\ ${ }^{3}$ Institute of Ocean Sciences, Sidney, British Columbia V8L 4B2, Canada
}

\begin{abstract}
In spite of being one of the most relevant components of the biosphere, the plankton-benthos network is still poorly studied as such. This is partly due to the irregular occurrence of driving phenomena such as gelatinous plankton pulses in this realm. Gelatinous plankters rely on their life cycles and histories to exploit temporarily abundant resources with an undeniable, but often overlooked, impact on marine food webs. Dramatic increases of gelatinous filter-feeders and/or carnivores (both native and nonindigenous species) are frequently observed, and explanations of these blooms alternatively invoke ecosystem variability, climate change, unspecified anthropogenic perturbation or removal of top predators from trophic networks. Gelatinous plankters, however, are not anomalies in plankton dynamics: the recognition of the ecological importance of their pulses, based on their life cycle patterns (often involving benthic stages), is a critical breakthrough to understand the cycling diversity of plankton in space and time. The current study focuses on the many neglected aspects of the ecology and biology of gelatinous zooplankton, describes how life cycle patterns are central in marine ecology, as are the pulses of gelatinous organisms, and highlights how such a dramatic lack of knowledge can affect our understanding of the marine ecosystem as a whole.
\end{abstract}

KEY WORDS: Gelatinous plankton · Resource patchiness $\cdot$ Life cycle $\cdot$ Life history $\cdot$ Cysts · Trophic networks · Benthic-pelagic coupling $\cdot$ Cnidaria $\cdot$ Ctenophora $\cdot$ Thaliacea

Resale or republication not permitted without written consent of the publisher

\section{INTRODUCTION}

Plankton represents a crossroad of aquatic biota which is of capital importance for the functioning of the biosphere in terms of both primary and secondary production. The gelatinous component of plankton 'mysteriously' appears (and disappears) at unpredictable times, and is usually considered as pertaining to the dark side of ecology (Benovic et al. 1987, Boero \& Mills 1997). Current conceptual models fail to provide a basis for accurate prediction of patterns and features of pelagic communities notably related to the spatial and temporal variability of the occurrence of specific organisms. However, this is a central issue for the development of reliable ecosystem models aimed, for instance, at the management of marine fisheries (Verity et al. 2002). Although the role of gelatinous plankton is increasingly attracting attention, the bulk of scientific literature (and research projects) focuses on phytoplankton, crustacean zooplankton and their relationships. The purpose of the current study is to draw attention to the oscillating nature of plankton abundance by focusing on gelatinous zooplankton and its potential key role in shaping marine communities. This underlines the ecological value of less-known life cycles and life history strategies adopted by gelatinous organisms, such as dormancy at different life stages.

\footnotetext{
${ }^{*}$ This text has been subject to peer review

${ }^{* *}$ Email: boero@unile.it

***These authors contributed equally to this work
} 


\section{PLANKTON PULSES}

Phytoplankton pulses are based on intense asexual reproduction of photosynthetic unicellular organisms. They rapidly build enormous populations, taking advantage of sudden favourable conditions that, usually, last for a short time (Valiela 1995). Phytoplankton is the main food source for herbivorous zooplankton, usually represented by crustaceans. The planktonic crustaceans, however, do not reproduce asexually, and their populations grow less quickly than those of the phytoplanktonic algae they feed upon (Fig. 1a). There are few exceptions to this rule, as conceivably parthenogenesis generates faster population growth (Cole 1954). However, basic differences in growth rates of phytoplankton (h) and zooplankton (d) can often lead to poor trophic phasing (Fig. 1b) (Parsons 1988), reducing the energy transfer efficiency in the pelagic domain but increasing the available resources for benthic filter-feeders (as sinking organic matter) (Riisgård et al. 1996, Gili \& Coma 1998).

The benefits of trophic phasing to either pelagic or benthic communities depend on the limiting factors acting on the potential growth rate of the phytoplankton (e.g. reduced light and less nutrients) (Tilman et al. 1982). For example, a spring phytoplankton bloom in clear water with a short but good supply of winter nutrients will generally produce phytoplankton much faster than can be consumed by the next trophic level (herbivorous zooplankton) (Fig. 1a). Therefore, a large supply of phytoplankton detritus will be available to the benthos. In contrast, a year-round supply of nutrients, such as in upwelling zones, may favour a slower and nutrient-controlled phytoplankton production, which the zooplankton can consume more efficiently (Fig. 1b).
The pulses of phyto- and zooplankton represent the driving machine of marine biota, quickly producing a bulk of biomass that will sustain marine food chains until the following plankton pulses are triggered by the cyclical occurrence of favourable environmental conditions (Boero 1994). In near-shore habitats both phyto- and zooplankton rely on benthic resting stages to survive the intervals between favourable periods and trigger new seasonal blooms (Boero et al. 1996, Marcus \& Boero 1998). However, oceanic dinoflagellates with reduced dormancy periods can also produce cysts (Meier et al. 2007), since resting stages can equally act as kernels of annual populations when suspended in the water column (Kirn et al. 2005). Thus, plankton ecology must highly regard both life cycle and life history patterns (Giangrande et al. 1994) in gaining an understanding of seasonal dynamics and blooms of plankters.

In spite of its overall importance, the planktonbenthos network is still far from being understood, and the irregular occurrence of plankton represents an obvious but serious practical constraint to the investigation of pelago-benthic interactions. Opposed to the almost regular occurrence of blooms of crustacean plankton, the pulses of gelatinous zooplankton are paradigmatic in this respect: they may last for rather short times, may occur over vast scales and are not recurrent on a regular basis (CIESM 2001, Kawahara et al. 2006). Despite such constraints, studies in the last 2 decades focusing on gelatinous zooplankton taxa revealed an underestimation of jellyfish importance in the pelagic food webs (Möller 1984, Båmstedt 1990, Schneider \& Behrends 1994, Behrends \& Schneider 1995, Olesen 1995, Boero \& Mills 1997, Purcell 1997, Mills 2001, Hansson et al. 2005, Møller \& Riisgård 2007).
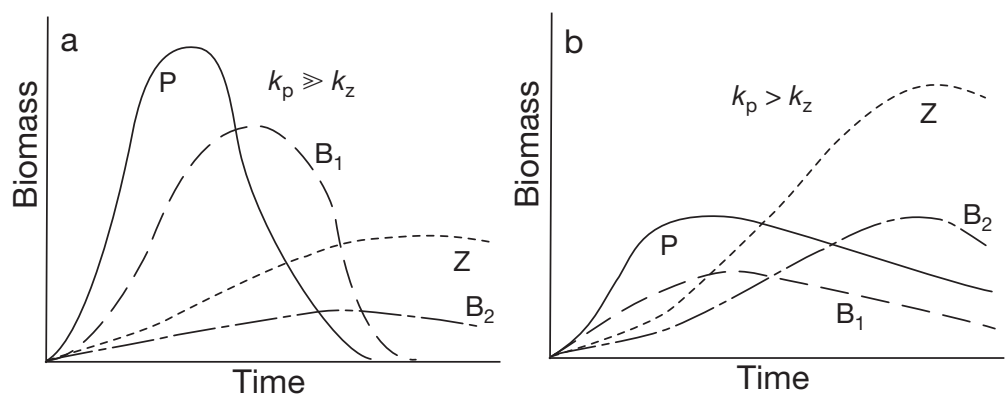

Fig. 1. Trophic phasing. (a) Poor trophic phasing (e.g. seasonal blooms in temperate areas); (b) Good trophic phasing (e.g. upwelling zones). $\mathrm{P}=$ phytoplankton, $\mathrm{Z}=$ zooplankton, $\mathrm{B}_{1}=$ sedimented phytoplankton, $\mathrm{B}_{2}=$ zooplankton detritus, $k_{\mathrm{p}}=$ relative growth rate of phytoplankton, $k_{\mathrm{z}}=$ relative growth rate of zooplankton. This simple model may not be helpful in explaining trophic level dynamics in oceanic oligotrophic gyres, where food web structure and primary productivity seem uncoupled, and the mechanisms that supply nutrients to the euphotic zone and maintain new production remain unsolved (Marañón et al. 2003)

\section{UNDENIABLE EVIDENCE}

...early in October of 1899 ... the sea looked as if converted into a solid mass of the jellyfish. The species had not been reported in Manx waters before, nor has it been seen there since. They appeared suddenly, remained for a short time, and as suddenly disappeared (Cole 1952).

Killer jellyfish destroy Ulster's only salmon farm (McDonald 2007)

The impact of gelatinous plankton predation on marine biota became too cogent to be neglected when Mnemiopsis leydi, an Atlantic ctenophore, was brought to the Black Sea, presumably by the ballast waters of oil tankers, and developed huge populations. Its mas- 
sive occurrence heavily contributed to the collapse of fisheries in the whole basin, impairing fish recruitment via predation on fish larvae and on their food (Brodeur et al. 2002, Volovik 2004). For the first time, in a dramatic way, it was clear that gelatinous carnivores can act as top predators, feeding on organisms that, when adult, should be at or near the apex of food chains. Fisheries models (e.g. Yodzis 2001, Riemann et al. 2006) include variables such as larval mortality and predation on larvae, but they do not consider in a realistic way the episodically exponential increase of the predatory impact of gelatinous organism blooms with high feeding rates and high reproductive potential (e.g. Mnemiopsis leidyi).

Over recent decades several cases of invasions of gelatinous plankters (medusae and/or ctenophores) or simple outbursts of indigenous jellyfish have been documented and/or reviewed (Brodeur et al. 1999, 2002, Mills 2001, Uye \& Ueta 2003, 2004, Volovik 2004, Purcell 2005, Xian et al. 2005, Kawahara et al. 2006, Link \& Ford 2006). These studies suggest several potential causal relationships between jellyfish mass occurrence and anthropogenic perturbations, such as global warming, eutrophication, overfishing (Mills 1995, CIESM 2001, Purcell et al. 2001, 2007, Daskalov 2002, Parsons \& Lalli 2002, Purcell 2005, Tatsuki 2005) or the increase of available hard substrates (e.g. dams, artificial reefs, shells from bivalve aquaculture), enhancing the chance for suitable planula settlement and subsequent ephyra production (Pagès 2001, Holst \& Jarms 2007). Nevertheless, unequivocal proof of sustained increases of jellyfish populations over recent years is lacking (Purcell et al. 2007). Historical plankton records, in fact, indicate that presumed exceptional jellyfish outbreaks of the present day (e.g. Pelagia noctiluca on the North Ireland coasts, see Sharrock 2007) were already described more than 100 years ago (Cole 1952, Russell 1970).

While the influence of unusually large populations of predators is often negative, gelatinous carnivores at low densities might represent a keystone guild (Piraino et al. 2002, Purcell \& Decker 2005). Feeding on eggs and larvae of potentially dominant nektonic species (Möller 1984, Purcell 1989), gelatinous carnivores might, in fact, reduce the success of these dominant species. This process can set resources free for previously outcompeted species, thus enhancing local diversity (Piraino et al. 2002).

Gelatinous plankton does not consist of predators only. Thaliaceans are gelatinous grazers, and their presence in the plankton is similarly pulsed, whereas larvaceans tend to have a more stable presence (Bone 1998). Thaliacean clearing rates are impressive and, because they can occur in enormous numbers, their impact on primary producers and on plankton- benthos carbon fluxes may be locally relevant (Zeldis et al. 1995, Bone 1998, Perissinotto \& Pakhomov 1998, CIESM 2001, Madin et al. 2006, Perissinotto et al. 2007). All gelatinous plankters, however, regardless of their trophic status, neither store much energy in the form of reserves nor do they generally perform, in the presence of currents, active migrations other than vertical. They thus mainly rely on their life cycles and histories to exploit abundant but temporary resources.

\section{LIFE CYCLES AND LIFE HISTORIES}

Plankton communities are often dominated by few abundant species, but these may change with time, giving rise to rapid temporal successions (Boero 1994). A species can be extremely abundant in a given period, rarely found for years or massively (and oddly) re-appear (Benovic et al. 1987, Goy et al. 1989). There are 2 main ways in which this may be accomplished: either via qualitative shifts at the individual level (i.e. life cycle adjustments) or via quantitative fluctuations at the population level (i.e. life history adjustments) (Giangrande et al. 1994). In the case of life cycle adjustments a species persists locally at different times during different life cycle stages. In the case of life history adjustments a species may undergo alternate and seasonal peaks of rarity and abundance in its adult populations.

Life cycle adjustments are the outcome of the evolution of life cycle stages able to escape into diapause or dormancy (i.e. resting stages) when resources are limiting. Resting stages may then produce active stages (juvenile and adult) when resources are not limiting and environmental conditions favour population growth (Uye 1985, Dahms 1995, Marcus 1996 for copepods; Edwards 1973, Boero et al. 1992 for Hydrozoa). For species with resting stages (known in several marine and freshwater planktonic taxa, i.e. dinoflagellates, tintinnids, cnidarians, rotifers, cladocerans and copepods), the absolute abundance (defined as the total number of individuals at all life cycle stages) may not fluctuate much in time (Fig. 2). The adults are present in pulses when conditions are optimal. New batches of larvae originate from resting stages, grow and reproduce, leading to population peaks. During the declining phase of the peak, the adults, instead of producing larvae, produce resting stages. If considered as a whole, each species is always represented by high numbers of individuals, albeit under different life cycle forms (e.g. Uye 1985).

Life history adjustments are, instead, the outcome of the population dynamics, i.e. changes of life history traits involve alternate periods of rarity and commonness. This brings great fluctuations of absolute abun- 
dances according to resource availability (Fig. 3). The number of individuals decreases at the end of the favourable season; the few remaining individuals start intense reproduction at the onset of the following favourable season, reaching abundance peaks. The population passes through continuous flushes and crashes, with sharp bottlenecks represented by periods of remarkably low abundance (Boero 1994).

Gelatinous organisms adopt both strategies. Holoplanktonic species, such as Ctenophora, Siphonophora, Tunicata, and some Hydrozoa and Scyphozoa, tend to perform life history adjustments, whereas meroplanktonic species with benthic stages, such as most Scyphozoa, Cubozoa and Hydrozoa, adopt life cycle adjustments. This is particularly true for coastal and neritic organisms (whose life cycles are known), but the hypothesis that suspended resting stages produced by open-water gelatinous metazoans may occur in the water column, as shown for phytoplankton cysts

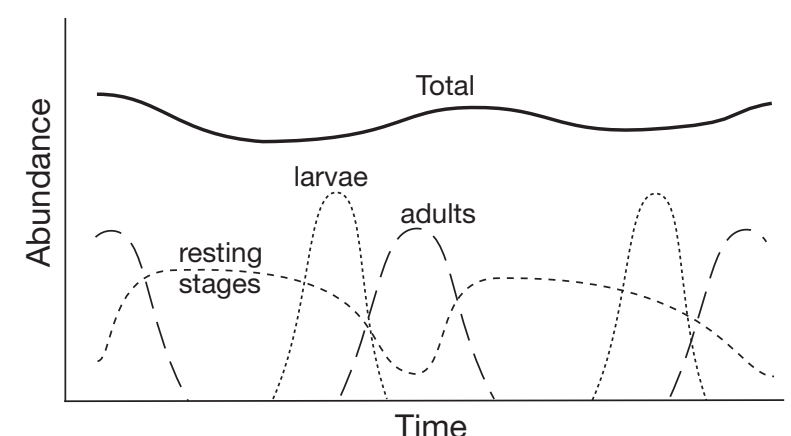

Fig. 2. Occurrence of a species performing life cycle adjustment to face seasonal resource availability. The total number of individuals (top line) in the population may remain grossly constant by shifting the ontogenetic stages at different times of the life span (from zygote to larva to adult, with the insertion of resting stages at different points)

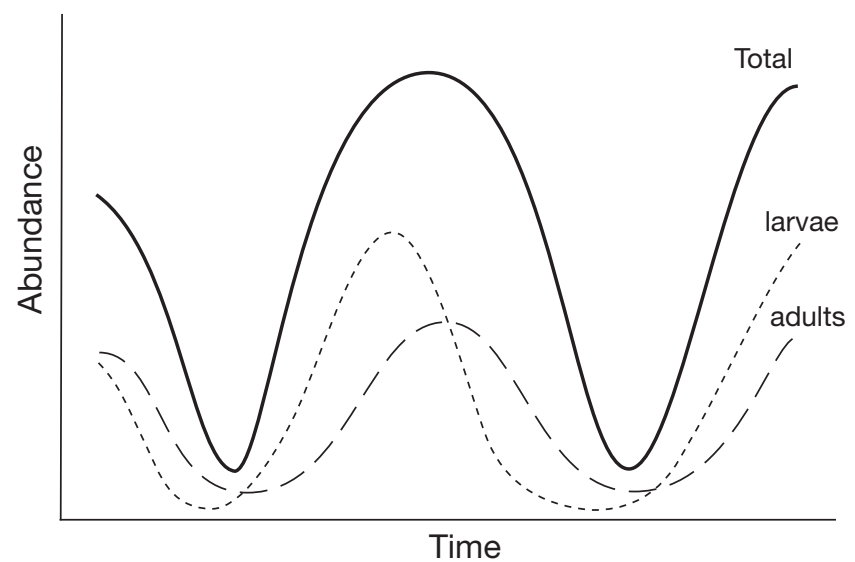

Fig. 3. Occurrence of a species performing life history adjustment to face seasonal resource availability. This leads to alternate periods of rarity and abundance
(Kirn et al. 2005), cannot be rejected a priori. In both cases (life cycle and life history adjustments), massive occurrences can be regularly spaced in time, with alternating periods of abundance and scarcity, but they are usually irregular with variable lags between successive peaks. Jellyfish proverbially go through peaks of abundance and then shrink to just a few or no individuals for many years, to suddenly reappear in unexpected multispecific blooms and even monospecific outbreaks (CIESM 2001, Purcell et al. 2001). The 2 strategies should not be considered as mutually exclusive, since they represent the extremes of a continuum, conceptually similar to the classical r-K continuum. Species persistence is gained by shifts in either the life cycle (favouring the most appropriate developmental stage: resting stage, larva, juvenile or adult) or the life history (with changes in population sizes, distribution ranges and life history traits) or both.

\section{DIAPAUSE, BENTHIC STAGES AND PLANKTON DYNAMICS: TWO DESCRIPTIVE MODELS}

Diapause is a predictive state of arrested development (dormancy) accompanied by adapted physiology for somatic persistence in response to the approach of unfavourable environmental conditions. The most popular marine plankton diapause stages are known for diatoms (Smetacek 1985), dinophytes (Dale 1983) and copepod (Lampert 1995, Marcus 1996, Belmonte 1997) and rotifer (Ricci 2001) embryos. Resting periods, however, may occur at different developmental stages, from the fertilized egg to the adult stage. As an example, hydrozoans (reviewed in Boero et al. 1997) may undergo diapause by formation of cysts shortly after metamorphosis or regression (at the polyp stage) into resting hydrorhizae, chitin-wrapped structures by which the colony fastens to the substrate. The presence of embryonic and larval cyst stages is known in Hydrozoa and ascribed to different taxa (e.g. Hydra, Margelopsis, Hataia, Paracoryne, Climacodon, Moerisia, Fukaurahydra, Corymorpha and Euphysa). Even if the number of species with recognized cysts is low (near $1 \%$ of the hydrozoan species), a detailed life cycle reconstruction by laboratory investigations (including experimental changes of environmental conditions) is lacking for the majority of species $(\leq 10 \%$ out of the 3702 known) (Bouillon et al. 2006). Therefore, given the high developmental plasticity of cnidarians, the formation of post-zygotic encystment is presumably a more common event than currently believed (Pagliara et al. 2000). Life cycle studies specifically targeted to the search of resting stages in gelatinous plankton are scant. As already stated, resting stages may be formed not only by encystment of embryos (from zygote to 
later stages until planulae), but also from fragments of hydranths, hydrocauli, hydrocladia or stolons. The polyps of most Antho- and Leptomedusae have resting hydrorhizae, and many species have special asexual propagules able to live for months (like frustules in Coryne, Craspedacusta, Scolionema, Obelia, Vallentinia, Gonionemus, Laomedea, Aglaophenia and Eucheilota) (Bouillon et al. 2006). This is also known in the Scyphozoa (Arai 1997).

Many plankters, thus, escape from limiting (climatic and biotic) conditions by entering the benthos as resting stages (see Parsons 1988, Boero et al. 1996 for reviews). The strategy is pursued by both phyto- and zooplankton, with great differences in their benthic stage biology. The seeding organisms leading to a population peak, in fact, derive from a reservoir of benthic resting stages that can either be individual (like the cysts of both protists and metazoans) or modular (like the colonies of Cnidaria). Moreover, plankters' resting stages can even remain viable for hundreds of years in the benthos, with a storage effect that recalls the ecological function of soil seed banks (Marcus et al. 1994, Hairston et al. 1995). The cysts remain buried in the sediments, and their only function is to survive until hatching, when they go back to the plankton (Clegg 1997).

As an example, 2 simple models may describe the life cycle patterns involving the presence of resting stages.

\section{Plankters with individual benthic stages}

The adults of many protists and crustaceans, at the end of a population peak, produce an a number of individual resting stages (e.g. cysts, spores, encysted eggs, embryos or diapausing juveniles) that usually spend their resting period in the benthos. At the onset of the following favourable period, an $a-b$ number of resting stages will hatch into active individuals that will 'seed' the new active population, where $b$ is the number of produced resting stages that will not hatch. The number $b$ is calculated from:

$$
b=d+\text { eld }
$$

where $d$ represents the dead resting stages and eld those entering extra-long diapause, remaining viable for future hatching. A complete figure of the year pattern describing the components of $\mathrm{N}$, the number of individuals triggering the new period of activity of the population, requires further adjustment, that is:

$$
\mathrm{N}=(a-b)+\text { held }
$$

where held refers to the number of hatched extra-longdiapausing stages stored in benthic seed banks by previous generations.
Diapause might lead a species to apparent rarity, since the absence of active forms, even over long periods, is counterbalanced by the abundance of resting stages (Fig. 2). If resting stages are not involved, however, rare species go through a real quantitative 'valley' (Fig. 3), waiting for the right occasion to become abundant.

The modern study of sudden disappearances and reappearances of marine plankters started when Werner (1954) identified benthic cysts in Margelopsis haeckeli, a hydrozoan species whose polyps and medusae both lead a planktonic life. The active stages co-occur and are sharply seasonal in North Sea plankton, so Werner asked an obvious (but seldom posed) question: 'where is plankton when it's not there?'. Werner became a pioneer in the ecology of marine resting stages, but his work was not widely cited by non-cnidarian specialists, so his ideas were confined to a small group of planktonologists.

\section{Plankters with modular benthic stages (the Cnidaria case)}

Generally, the functional role of modular organisms in ecosystems is poorly investigated because of the inherent difficulties in studying their biology. The most influential book on the evolution of life histories (Stearns 1992), for instance, considers only colonial organisms to the extent of labelling them as being 'different' from aclonal ones. Medusozoa belong to this neglected group as most of them have a benthic, feeding and modular stage (the polyp).

A single event of fertilisation does not lead to a single new specimen but to a colony that will produce a batch of medusae several times over the years (Fig. 4). Thus, a new factor $M$ (modularity) is necessary to represent the number of benthic modules triggering a new planktonic population. $M$ is species specific. It can be calculated by multiplying $g$, i.e. the number of gonophores or strobilas (reproductive structures) produced by an average colony, by $m$, the number of medusae produced by each gonophore or strobila during every favourable season. The future injection of medusae $(n)$ in the water column can be estimated by multiplying the number of active colonies $[(a-b)+$ held $]$ by the specific $M$ value $(\mathrm{gm})$ :

$$
n=[(a-b)+\text { held }](M)
$$

The presence of colonies, however, does not necessarily imply medusa production (Edwards 1973). Colonies, in fact, can be active for long periods and grow for many years without producing medusae. This could be considered equivalent to an extra-long resting stage that, however, feeds and grows even without producing new adult stages (the medusae). On the 


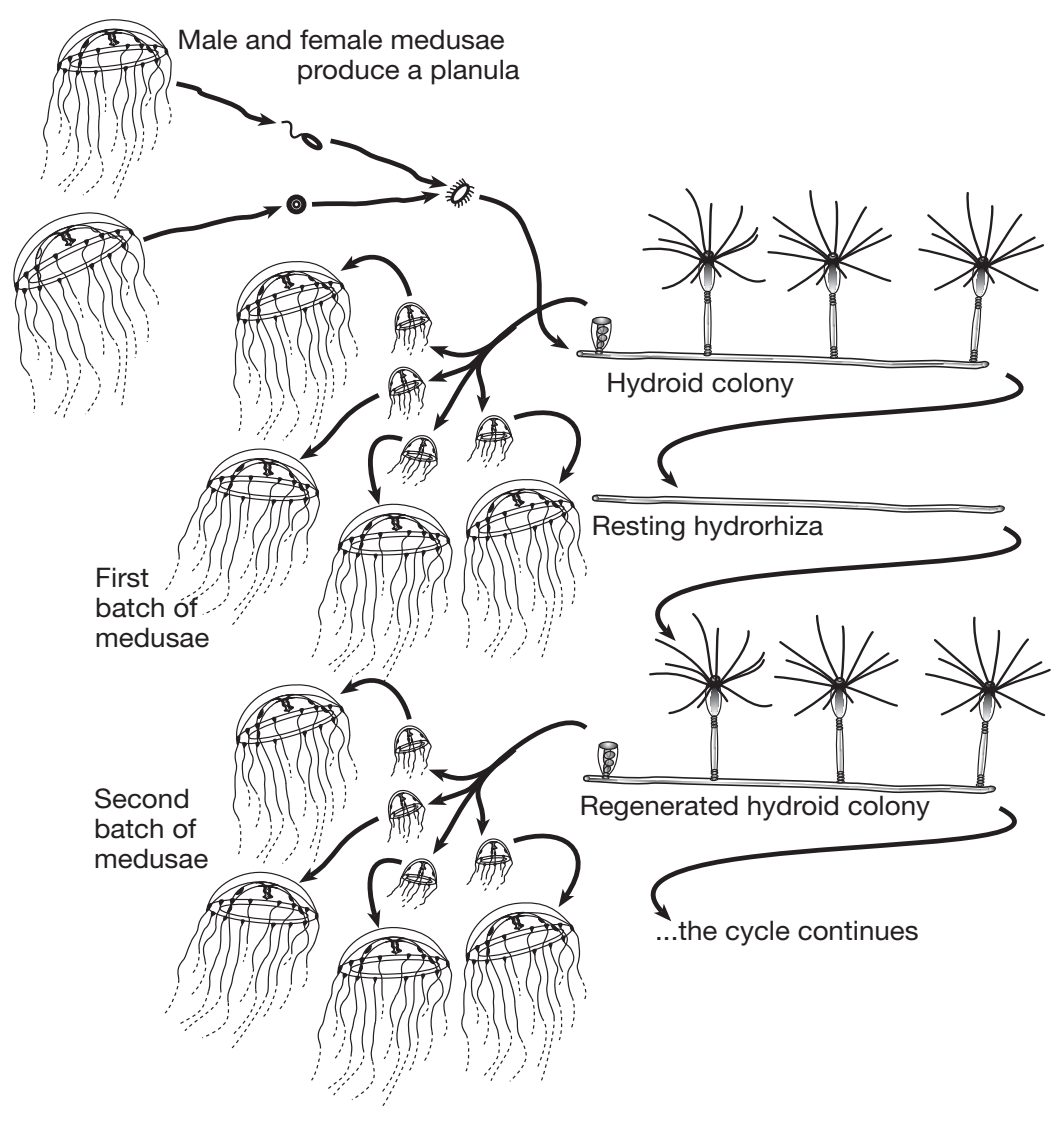

Fig. 4. The life cycle of pelago-benthic jellyfish. From a single event of fertilization, the polyp stage arises after metamorphosis of the short-lived planula stage. Polyps can be interpreted as a secondary larval stage. They can be present as active, feeding stages able to acquire resources from the environment or as resting stages in the form of quiescent hydrorhiza when environmental conditions are not favourable. At the onset of the new favourable season, new polyps are generated from the hydrorhizal stolons, and new medusae will be produced by the regenerated colonies. The iterative multiplication (asexual reproduction) of the polyp stage results in the production of a great number of medusae from a single fertilized egg and for several years

other hand, a single colony can produce medusae for many years (Fig. 4). Moreover, N in Eq. (2) and $n$ in Eq. (3) both coincide with the starting population size $\mathrm{N}_{0}$ in the exponential curve of population growth $\left(\mathrm{N}_{t}=\right.$ $\mathrm{N}_{0} \mathrm{e}^{\mathrm{kt}}$ ) and a massive buildup in this value over time $(t)$ can assure a large outbreak $\left(\mathrm{N}_{t}\right)$ even when the growth rate $(k)$ may not be exceptionally high. Thus, jellyfish blooms can be explained by the intrinsic starting value of $\mathrm{N}_{0}$, highly dependent on the modularity factor and the potential for asexual reproduction, as well as the onset of favourable growth conditions.

Colonies, thus, can be active without producing medusae, but they can also 'functionally' disappear while remaining structurally present. After a trophic and reproductive period, colonies can regress to resting stolons, spend the adverse season as such and become active again at the onset of the following favourable season (Boero 1984, Gili \& Hughes 1996, Bouillon et al.
2006) (Fig. 4). The alternate presence of polyps and medusae may allow a given species to persist under different environmental conditions and pressures, being represented by 2 morphs (the polyp and the medusa) with sharply different traits (Table 1).

A jellyfish outbreak can therefore be triggered by extremely successful benthic stages that injected the water column with innumerable medusae. Knowledge from natural history of Medusozoa provides evidence of this multiplicative pattern. Indeed, even though in situ quantitative countings are missing, it is known that several taxa have polyps with multiple medusa budding, each polyp colony bearing several medusa buds at the same time (Bouillon 1995, Boero et al. 2002, Bouillon et al. 2006). Under laboratory conditions a single colony of the marine hydrozoan Hydractinia carnea can produce thousands of medusae per week (Schmid 1979). This means that settlement of each planula in the field may result in the exponential fuelling of jellyfish populations, if suitable environmental conditions are encountered for colony growth. Such potential for exponential jellyfish production is even greater. In fact, medusa bud development usually takes place within a few days. In most hydrozoans (including species with a single bud per polyp) the temporal windows for medusa budding last several weeks or months, that is, medusa budding is not only high, but also prolonged in time (Boero et al. 1992) (Fig. 4). Furthermore, several medusae retain a high potential of asexual reproduction, as they also multiply by directly budding off new medusae, and the daughter medusae may, in turn, bud off again and so on. This type of medusa budding may take place at various levels (Boero et al. 2002, Bouillon et al. 2006): manubrium, radial canals, tentacular bulbs, exumbrellar rim, circular canal, subumbrellar rim and gonads.

In the Scyphozoa, polydisk strobilation allows single polyps to produce large numbers of ephyrae. Cubozoa can switch from the usual metamorphosis of the polyp stage into a sort of monodisk strobilation, leaving a remnant that regenerates into a new complete polyp (second order). By asexual reproduction, this polyp will bud new secondary polyps able to metamorphose into multiple copies of the medusa stage (Straehler-Pohl \& 
Table 1. Comparison of the main traits of hydrozoan medusae and polyps. The superclass Hydrozoa of the phylum Cnidaria comprises 3702 species currently regarded as valid and ascribed to 3 heterogeneous classes (Bouillon et al. 2006). The 134 species of the class Automedusa have simple life cycles with medusae and no polyp stage and are divided into 3 subclasses: Actinulidae, Narcomedusae and Trachymedusae. The 3567 species of the class Hydroidomedusa have complex life cycles with polyps producing medusae through a medusary nodule; they are divided into 5 subclasses: Anthomedusae, Laingiomedusae, Leptomedusae, Limnomedusae and Siphonophorae. The 2 stages of the same life cycle are often treated as pertaining to different species. The table provides a list of evolutionary relevant traits to explain the occurrence of different rates of evolution ('inconsistent evolution', see Naumov 1969, Boero \& Bouillon 1987) in the polyp and the medusa stages. These differences drove taxa belonging to many families $(>50 \%$ ) to the paedomorphic reduction of the medusa stage and to a wider diversification of the polyp stages

\begin{tabular}{|lll|}
\hline Feature / stage & Medusa & Polyp \\
\hline Body plan & Individual & Modular \\
Asexual reproduction & Usually low & Usually high \\
Morphological diversification & Low (bell, manubrium, tentacles) & High (polymorphic colonies) \\
Life span & Short (from hours to a few months) & Long (many years) \\
Life style & Planktonic (some benthic) & Benthic, sessile (some planktonic) \\
Habitat heterogeneity & Low (the water column) & High (all bottom types, epibiosis) \\
Types of feeding & Carnivore, few algal symbionts & Carnivore, particulate organic matter, \\
& & algal symbionts \\
Food availability & Fluctuating & Fluctuating or constant \\
Trophic position & Apex of food chains & From apex to bottom of food chains \\
Niche differentiation & Low & High \\
Potential interspecific competition & High & Low \\
\hline
\end{tabular}

Jarms 2005). In summary, then, the developmental potential for large and sudden jellyfish production is known throughout the whole Medusozoa (Hydrozoa, Scyphozoa and Cubozoa).

After sexual reproduction senescent medusae generally die, but exceptions are known: several cnidarians retain the potential for ontogeny reversal (Piraino et al. 2004). Since the discovery of the potential of Turritopsis medusae for reverse ontogeny (Bavestrello et al. 1992), additional species with the same developmental plasticity have been observed (Piraino et al. 2004, De Vito et al. 2006), indicating that this potential might be more common than previously thought. In addition, the new polyp stages resulting from the normal ontogenetic cycle (by egg fertilization and embryonic and larval development) will fuel the benthic reservoir for future outbreaks (Fig. 4). Small hydromedusae, due to the peculiarities of their life cycles, are probably the most widespread and diverse representatives of gelatinous plankton. Yet they are usually neglected in plankton ecology because they are inconspicuous, escape direct observation, and their occurrence is sharply seasonal. Summing up the predatory impacts of both medusae and polyps (Madin et al. 1996, Gili et al. 1998, CIESM 2001, Purcell et al. 2001), it is clear that the ecological importance of these animals is underestimated.

Some taxa without known benthic modular stages produce rapid blooms by asexual reproduction. This is true for modular gelatinous plankters such as siphonophores (e.g. Purcell 1981) and Thaliacea (Bone 1998). Benthic resting stages are also unrecorded for Ctenophora. Besides a high potential for regeneration, ctenophores do not show other types of asexual reproduction (e.g. fission), largely relying on sexual reproduction to increase individual number. High fecundity, rapid generation time and ability to self-fertilize may explain ctenophore sudden appearance in bloom proportions at periods of high food concentration in the environment (Baker \& Reeve 1974).

\section{A BIASED PICTURE}

The study of zooplankton has been oriented towards organisms whose size, body structure and spatial and temporal distribution can be reliably detected with traditional methods. Conventional plankton nets are effective to collect crustaceans and other taxa with inner skeletal structures or cuticular outer layers, but different devices are needed to keep records of the abundance, distribution and behaviouraltrophic ecology of soft-bodied plankters. Especially to investigate large jellyfish aggregations, in situ acoustic or optical devices are useful to cope with the patchiness of the spatial distribution of specimens (Graham et al. 2003). The watery bodies of gelatinous plankters are heavily damaged by plankton tows, often posing impenetrable questions of taxonomy and systematics. However, in situ trawl videography, remotely operated vehicles, submersibles and echosounders are rarely used in conjunction with conventional nets in most plankton investigations, due to their high operational costs. Blue-water SCUBA diving (Hamner et al. 1975) was until recently the most readily available approach for in situ gelatinous zoo- 
plankton investigation, but this method is very resticted by the narrow spatial and temporal extension of SCUBA dives.

Boero \& Mills (1997) remarked that a crustaceanfocused study of plankton without proper consideration of the gelatinous component is as incomplete as a hypothetical study of the ecology of the Serengeti through observations of zebras and gnus only. This would surely offer a biased picture, as it would ignore not only lions and cheetahs (jellyfish and ctenophores) but also antelopes (thaliacea)! Filter-feeding gelatinous tunicates, in fact, can be very abundant (in spite of being difficult to catch) and can filter as much phytoplankton as copepods, if not more (Zeldis et al. 1995, Bone 1998, Perissinotto \& Pakhomov 1998, Perissinotto et al. 2007).

The bentho-pelagic cycles typical of most jellyfish might be a shared feature with many taxa currently considered as 'holopelagic' (Parsons 1988) (Fig. 5). Jellyfish have obvious benthic stages (polyp colonies), which have been studied with great care, often by specialists devoted to polyps only. In spite of some wellstudied crustacean exceptions (e.g. copepods and cladocerans), many coastal plankters have benthic (resting) stages that are so inconspicuous as to escape observation by researchers who do not have the specific purpose of finding them (Boero et al. 1996). There is no theoretical justification for assuming that the benthic resting stages of planktonic organisms are ecologically unimportant, especially because many key species of coastal food webs have been shown to enter resting phases in sediments (Marcus 1996). Unfortunately, despite all the recent advances in plankton lifecycle research, plankters with benthic resting stages are still assumed to be exceptions. However, resting

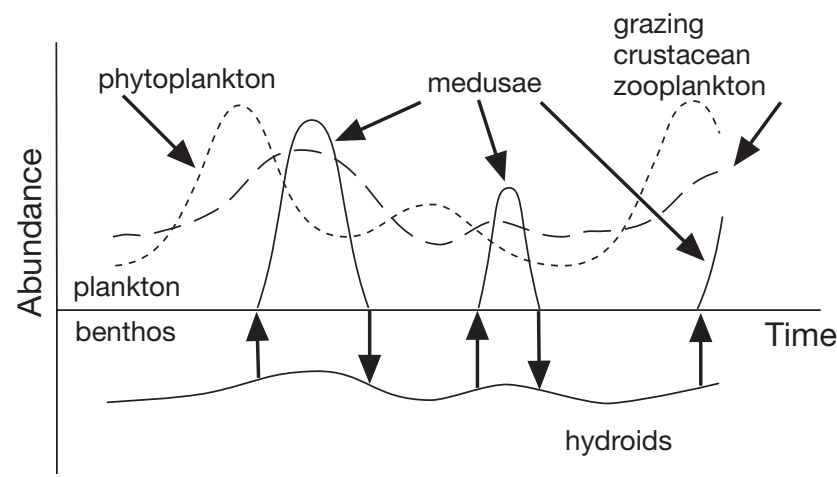

Fig. 5. Life cycle strategies of medusae with benthic polyps. Peaks of abundance in the plankton are tuned to food availability. Exploitation of trophic resources leads to sexual reproduction and larval development, followed by disappearance of adult medusae from the water column and planula metamorphosis into the polyp benthic stage. Polyps have a continuous presence in the benthos, either as resting hydrorhizae or as actively feeding colonies that will seed the next generation of medusae stages seem to be an important component in meiofaunal ecology (Pati et al. 1999) or in shallow-deep-sea coupling (Della Tommasa et al. 2000) and, with the advancement of life-cycle oriented research, these exceptions are increasingly becoming the 'rule' (e.g. Kremp \& Parrow 2006, Kim et al. 2007, Meier et al. 2007).

The main planktonic production pathways and their links to the benthos can be summarized as follows (Fig. 6). All organisms, with their metabolic wastes first and with their dead bodies later, contribute to the pool of organic matter to be processed by heterotrophic bacteria acting as decomposers. Bacterial decomposition leads to nutrient mineralization, fuelling (together with the nutrients from terrestrial runoffs) the blooms of microbial autotrophic production, the phytoplankton. Bacteria, through the microbial pathway, are preyed upon by heterotrophic protists. Zooplanktonic filter-feeders (often labeled as herbivores), mainly crustaceans, use both bacteria and autotrophic and heterotrophic protists as a food source. Crustaceans link phytoplankton production to the nekton, which is mostly composed of carnivorous vertebrate species that will progressively switch from planktonic to nektonic food sources as they increase in size.

Gelatinous organisms can short-circuit the microbescrustacean herbivores-nekton pathway at 2 levels. Gelatinous herbivores (salps, doliolids, pyrosomes and appendicularians) can deplete microbial populations with their blooms, thus impairing the energy flow which, from microbial production through the crustacean zooplankton pathway, fuels the nekton. Gelatinous herbivores usually contribute to marine snow and their dead bodies sink to the bottom, directly fuelling the benthic compartment. Gelatinous carnivores (medusae, siphonophores and ctenophores) can affect nekton in the pelagic web, both by competition (by feeding on the potential prey of fish: the crustaceans) and by direct predation on nekton (feeding on fish eggs and larvae) (Sanvicente-Añorve et al. 2006, Titelman \& Hansson 2006, Møller \& Riisgård 2007). Both phytoplankton and grazing zooplankton are the energetic basis for the peaks of medusan abundance (Figs. 4 \& 5). Finally, planktonic organisms and organic matter sink towards the benthos, providing energy to benthic systems where, in shallow waters, important processes of primary production occur via micro- and macroalgae and seagrasses.

Both the microbial and the crustacean-nekton pathways occur more or less regularly and their representatives can always be found in plankton samples. Gelatinous pathways, on the other hand, are often absent but, occasionally, can play overwhelming roles with their pulses for much longer than they actually occur: irregularities rule the world (sometimes). 


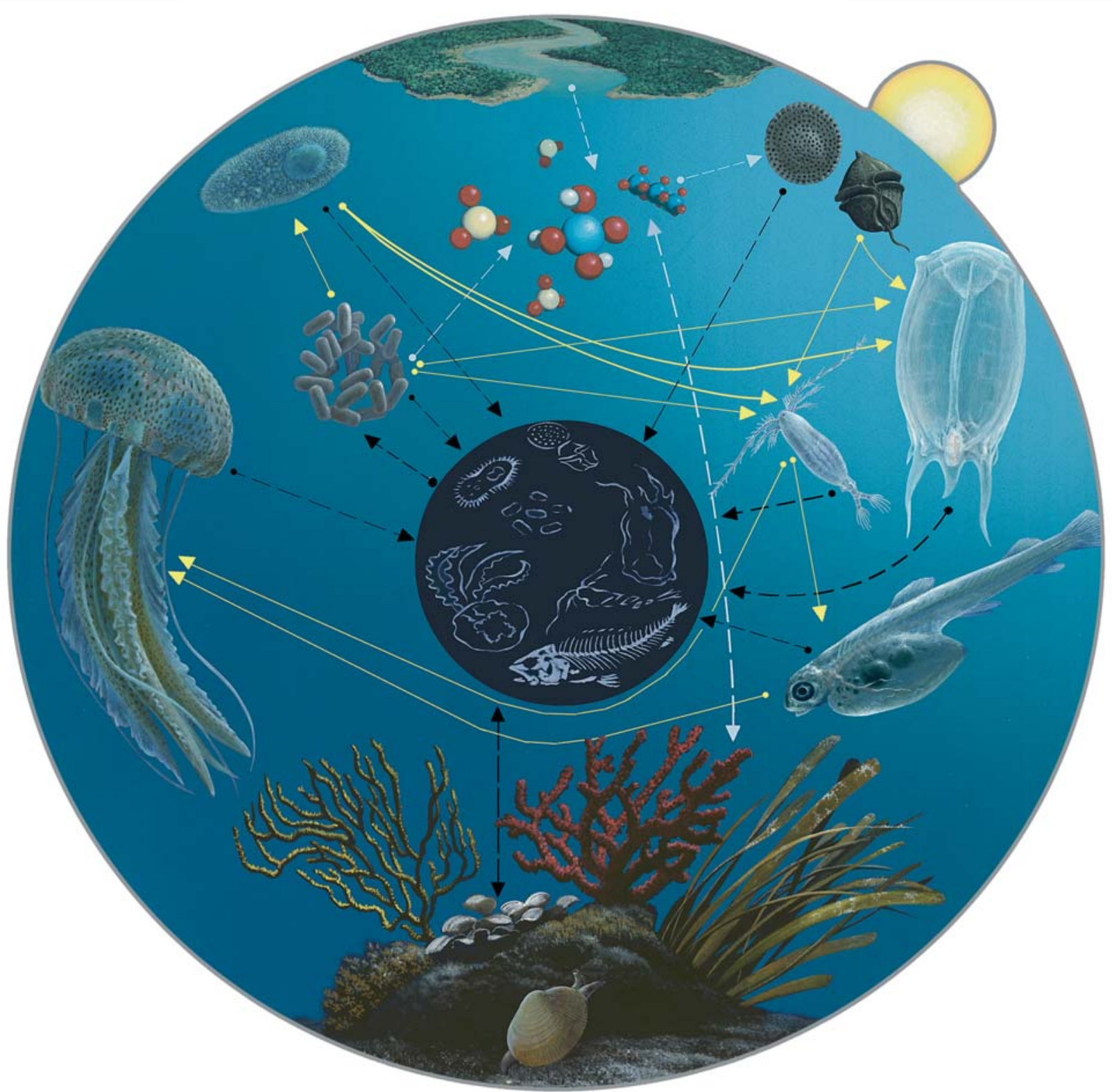

Fig. 6. Schematic representation of the main trophic pathways in the water column (art by Alberto Gennari and Fabio Tresca). Organic matter is mineralized by heterotrophic bacteria that make nutrients available for phytoplankton growth, fuelled also by terrestrial runoffs. Bacteria can be consumed in the flagellates-based, low-energy food chains (sensu Parsons \& Lalli 2002). Heterotrophic, autotrophic, and mixotrophic bacteria, along with protists, form the microbial pathway. They fuel the classical crustacean-vertebrate pathway, but they can also fall in the sink of gelatinous herbivores. The gelatinous carnivores' pathway is a sink for the crustacean-nekton pathway. Water column organisms, either dead or alive, tend to sink to the bottom, where they make contact with the benthic domain, from where organic matter and organisms can be resuspended by turbulence, upwellings and active migration. White arrows represent biogeochemical fluxes. Black arrows represent fluxes of particulate organic matter. Yellow arrows represent trophic links

\section{EPILOGUE: FROM FISH TO JELLYFISH?}

The emphasis given to regularly occurring organisms should be corrected, especially in the pelagic domain (i.e. neritic and oceanic water columns, the most widespread environments of the planet), with recognition of the importance of episodic blooms of both herbivore and carnivore gelatinous plankters. Their sudden and brief occurrence is not an anomaly but an adaptation that takes advantage of fluctuating resource availability. Human activities, especially overfishing, can force marine food webs toward the increase of jellyfish abundances (CIESM 2001, Mills 2001, Purcell et al. 2001, Niermann 2004, Lynam et al. 2005, Xian et al. 2005, 
Hay 2006, Daskalov et al. 2007). Using a meta-analytic approach, Myers \& Worm $(2003,2005)$ estimated a $90 \%$ depletion of predatory fish communities in coastal regions worldwide. In this framework, the decline of large, long-lived predators and the transition to shortlived invertebrates and planktivorous fishes (Pauly et al. 1998) may have potentially serious effects on ecosystems that could lead to a top-down control of marine food webs by gelatinous predators (Mills 2001).

Cnidarian dominance of the world's oceans goes back 500 million years (Myr), well before the evolution of fish and marine mammals, and it was probably asserted by the same life cycle strategies as have been described above (Mills 2001, Parsons \& Lalli 2002). The jellyfish of $500 \mathrm{Myr}$ ago can be astonishingly similar to recent ones (Cartwright et al. 2007). The evolution of the more energetic life forms, such as fish (ca. $300 \mathrm{Myr}$ ago) and whales (ca. 100 Myr ago) may have been sustained by the enrichment of the plankton community that resulted in a higher supply of energy in the marine food chain (Parsons 1979, Parsons \& Lalli 2002). Human impacts that are affecting this evolutionary chain of events include overfishing and climate change: the former is vacating the role of top predators and the latter is causing the formation of more temperaturestable water masses with less nutrients. These direct and indirect effects may be causing a suppression of high-energy (fish and whales) food chains with a possible subsequent de-evolution of the pelagic marine ecosystem back to a Medusozoan dominance. In this scenario, the understanding of ecological dynamics of gelatinous zooplankton becomes an impelling priority both in marine biology and conservation.

Acknowledgements. Financial support by MURST (60\%, COFIN and FIRB Projects), the Administration of the Province of Lecce, ICRAM (Project 'Cnidarian exotic species in the Mediterranean sea'), the European Commission (Marie Curie contract no. HPMD-CT-2001-00099, IASON, the MARBEF network, the SESAME project-EC Contract No. GOCE036949, funded by the Sixth Framework Programme under the priority 'Sustainable Development, Global Change and Ecosystems'), the NSF of the USA (PEET project on the Hydrozoa), the 'Centro EuroMediterraneo per i cambiamenti climatici' and the Smithsonian Marine Science Network postdoctoral fellowship to M.P.M. This paper is dedicated to the memory of Francesc Pagès (1962-2007), an outstanding figure in the study of gelatinous plankton diversity.

\section{LITERATURE CITED}

Arai MN (1997) A functional biology of Scyphozoa. Chapman \& Hall, London

Baker LD, Reeve MR (1974) Laboratory culture of the lobate ctenophore Mnemiopsis mccradyi with notes on feeding and fecundity. Mar Biol 26:57-62

Båmstedt U (1990) Trophodynamics of the scyphomedusae Aurelia aurita. Predation rate in relation to abundance, size and type of prey organism. J Plankton Res 12:215-229
Bavestrello G, Sommer C, Sarà M (1992) Bi-directional conversion in Turritopsis nutricula. In: Bouillon J, Boero F, Cicogna F, Gili JM, Hughes RG (eds) Aspects of hydrozoan biology. Sci Mar 56:137-140

Behrends G, Schneider G (1995) Impact of Aurelia aurita medusae (Cnidaria, Schyphozoa) on the standing stock and community composition of mesozooplankton in the Kiel Bight (western Baltic Sea). Mar Ecol Prog Ser 127:39-45

Belmonte G (1997) Morphological convergence of resting stages of planktonic organisms: a review. Hydrobiologia 355:159-165

Benovic A, Justic D, Bender A (1987) Enigmatic changes in the hydromedusan fauna of the northern Adriatic Sea. Nature 326:597-600

Boero F (1984) The ecology of marine hydroids and effects of environmental factors: a review. PSZN I: Mar Ecol 5:93-118

Boero F (1994) Fluctuations and variations in coastal marine environments. PSZN I: Mar Ecol 15:3-25

Boero F, Bouillon J (1987) Inconsistent evolution and paedomorphosis among the hydroids and medusae of the Athecatae/Anthomedusae and the Thecatae/Leptomedusae (Cnidaria, Hydrozoa). In: Bouillon J, Boero F, Cicogna F, Cornelius PFS (eds) Modern trends in the systematics, ecology and evolution of hydroids and hydromedusae. Clarendon Press, Oxford, p 229-250

> Boero F, Mills CE (1997) Agricultural versus ethological oceanography. Trends Ecol Evol 12:208-209

Boero F, Bouillon J, Piraino S (1992) On the origins and evolution of hydromedusan life cycles (Cnidaria, Hydrozoa). In: Dallai R (ed) Sex origin and evolution. Selected Symposia and Monographs UZI 6:59-68

Boero F, Belmonte G, Fanelli G, Piraino S, Rubino F (1996) The continuity of living matter and the discontinuities of its constituents: do plankton and benthos really exist? Trends Ecol Evol 11:177-180

Boero F, Bouillon J, Piraino S, Schmid V (1997) Diversity of hydrozoan life cycles: ecological implications and evolutionary patterns. Proc 6th Int Conf on Coelenterate Biology, 1995. Nationaal Natuurhistorisch Museum, Leiden, p 53-62

Boero F, Bouillon J, Piraino S, Schmid V (2002) Asexual reproduction in the Hydrozoa (Cnidaria). In: Hughes RN (ed) Reproductive biology of invertebrates XI: progress in asexual reproduction. Oxford and IBH Publishing Co., New Delhi, p 141-158

Bone Q (1998) The biology of pelagic tunicates. Oxford University Press, Oxford

Bouillon J (1995) Classe des Hydrozoaires. In: Grassé PP, Doumenc D (eds) Traité de zoologie 3. Masson, Paris, p 29-416

Bouillon J, Gravili C, Pagès F, Gili JM, Boero F (2006) An introduction to Hydrozoa. Mem M Nat Hist Nat 194

Brodeur RD, Mills CE, Overland JE, Walters GE, Schumacher JD (1999) Evidence for a substantial increase in gelatinous zooplankton in the Bering Sea, with possible links to climate change. Fish Oceanogr 8:296-306

Brodeur RD, Sugisaki H, Hunt GL (2002) Increases in jellyfish biomass in the Bering Sea: implications for the ecosystem. Mar Ecol Prog Ser 233:89-103

Cartwright P, Halgedahl SL, Hendricks JR, Jarrad RD, Marques AC, Collins AG, Lieberman BS (2007) Exceptionally preserved jellyfishes from the Middle Cambrian. PLoS ONE 2(10):1-7

CIESM, The Mediterranean Science Commission (2001) Gelatinous zooplankton outbreaks: theory and practice. CIESM Workshop Monographs 14:1-112. Also available at: www.ciesm.org/online/monographs/index.html

Clegg J (1997) Embryos of Artemia franciscana survive four years of continuous anoxia: the case for complete meta- 
bolic rate depression. J Exp Biol 200:467-475

Cole FJ (1952) Pelagia in Manx waters. Nature 170:587

Cole LC (1954) The population consequences of life history phenomena. Q Rev Biol 29:103-137

Dahms HU (1995) Dormancy in the copepoda-an overview. Hydrobiologia 306:199-221

Dale B (1983). Dinoflagellate resting cysts: 'benthic plankton'. In: Fryxell GA (ed) Survival strategies of the algae. Cambridge University Press, New York, p 69-136

> Daskalov GM (2002) Overfishing drives a trophic cascade in the Black Sea. Mar Ecol Prog Ser 225:53-63

Daskalov GM, Grishin AN, Rodionov S, Mihneva V (2007) Trophic cascades triggered by overfishing reveal possible mechanisms of ecosystem regime shifts. Proc Natl Acad Sci USA 104:10518-10523

Della Tommasa L, Belmonte G, Palanques A, Puig P, Boero F (2000) Resting stages in a submarine canyon: a component of shallow-deep-sea coupling? Hydrobiologia 440: 249-260

$>$ De Vito D, Piraino S, Schmich J, Bouillon J, Boero F (2006) Evidence of reverse development in Leptomedusae (Cnidaria, Hydrozoa): the case of Laodicea undulata (Forbes and Goodsir 1851). Mar Biol 149:339-346

Edwards C (1973) Contributory thoughts on form, function, habitat and classification of hydroids and hydromedusae. Publ Seto Mar Biol Lab 20:11-22

Giangrande A, Geraci S, Belmonte G (1994) Life cycle and life history diversity in marine invertebrates and the implications in community dynamics. Oceanogr Mar Biol Annu Rev 32:305-333

Gili JM, Coma R (1998) Benthic suspension-feeders: their paramount role in littoral marine food webs. Trends Ecol Evol 13:316-321

Gili JM, Hughes RG (1996) The ecology of marine benthic hydroids. Oceanogr Mar Biol Annu Rev 33:351-426

Gili JM, Alvà V, Coma R, Orejas C and others (1998) The impact of small benthic passive suspension-feeders in shallow marine ecosystems: the hydroids as an example. Zool Verh 323:99-105

> Goy J, Morand P, Etienne M (1989) Long-term fluctuations of Pelagia noctiluca (Cnidaria, Schyphomedusa) in the western Mediterranean Sea. Prediction by climatic variables. Deep-Sea Res 36:269-279

Graham WM, Martin DL, Martin JC (2003) In situ quantification and analysis of large jellyfish using a novel video profiler. Mar Ecol Prog Ser 254:129-140

Hairston NG, Van Brunt A, Kearns CM, Engstrom DR (1995) Age and survivorship of diapausing eggs in a sediment egg bank. Ecology 76:1706-1711

Hamner WM, Madin LP, Alldredge AL, Gilmer RW, Hamner PP (1975) Underwater observation of gelatinous zooplankton: sampling problems, feeding biology and behaviour. Limnol Oceanogr 20:907-917

Hansson LJ, Moeslund O, Kiørboe T, Riisgård HU (2005) Clearance rates of jellyfish and their potential predation impact on zooplankton and fish larvae in a neritic ecosystem (Limfjorden, Denmark). Mar Ecol Prog Ser 304: 117-131

Hay S (2006) Marine ecology: gelatinous bells may ring change in marine ecosystems. Curr Biol 16:R679-R682

Holst S, Jarms G (2007) Substrate choice and settlement preferences of planula larvae of five Scyphozoa (Cnidaria) from German Bight, North Sea. Mar Biol 151:863-871

Kawahara M, Uye S, Ohtsu K, Iizumi H (2006) Unusual population explosion of the giant jellyfish Nemopilema nomurai (Scyphozoa: Rhizostomeae) in East Asian waters. Mar Ecol Prog Ser 307:161-173

Kim CJ, Kim HG, Kim CH, Oh HM (2007) Life cycle of the ichthyotoxic dinoflagellate Cochlodinium polykrikoides in Korean coastal waters. Harmful Algae 6:104-111
Kirn SL, Townsend DW, Pettigrew NR (2005) Suspended Alexandrium spp. hypnozygote cysts in the Gulf of Maine. Deep-Sea Res II 52:2543-2559

Kremp A, Parrow MW (2006) Evidence for asexual resting cysts in the life cycle of the marine peridinoid dinoflagellate Scripsiella hangoei. J Phycol 42:400-409

Lampert W (1995) Egg bank investment. Nature 377:479

Link JS, Ford MD (2006) Widespread and persistent increase of Ctenophora in the continental shelf ecosystem off NE USA. Mar Ecol Prog Ser 320:153-159

Lynam CP, Heath MR, Hay SJ, Brierley AS (2005) Evidence for impacts by jellyfish on North Sea herring recruitment. Mar Ecol Prog Ser 298:157-167

Madin LP, Bollens SM, Horgan E, Butler M and others (1996) Voracious planktonic hydroids: unexpected predatory impact on a coastal marine ecosystem. Deep-Sea Res II 43:1823-1829

Madin LP, Kremer P, Wiebe PH, Purcell JE, Horgan EH, Nemazie DA (2006) Periodic swarms of the salp Salpa aspera in the Slope Water off the NE United States: biovolume, vertical migration, grazing and vertical flux. DeepSea Res I 53:804-819

Marañón E, Behrenfeld MJ, González N, Mouriño B, Zubkov MV (2003) High variability of primary production in oligotrophic waters of the Atlantic Ocean: uncoupling from phytoplankton biomass and size structure. Mar Ecol Prog Ser 257:1-11

> Marcus NH (1996) Ecological and evolutionary significance of resting eggs in marine copepods: past, present and future studies. Hydrobiologia 320:141-152

Marcus NH, Boero F (1998) Production and plankton community dynamics in coastal aquatic systems: the importance of benthic-pelagic coupling and the forgotten role of life cycles. Limnol Oceanogr 43:763-768

Marcus NH, Lutz R, Burnett W, Cable P (1994) Age, viability and vertical distribution of zooplankton resting eggs from an anoxic basin: evidence of an egg bank. Limnol Oceanogr 39:154-158

McDonald H (2007) Killer jellyfish destroy Ulster's only salmon farm. The Guardian, November 22, 2007 , Manchester. Available at: www.guardian.co.uk/uk/2007/ nov/22/northernireland.lifeandhealth

Meier KJS, Young JR, Kirsch M, Feist-Burkhardt S (2007) Evolution of different life cycle strategies in oceanic calcareous dinoflagellates. Eur J Phycol 42:81-89

Mills CE (1995) Medusae, siphonophores and ctenophores as planktivorous predators in changing global ecosystems. ICES J Mar Sci 52:575-581

Mills CE (2001) Jellyfish blooms: are populations increasing globally in response to changing ocean conditions? Hydrobiologia 451:55-68

Möller H (1984) Reduction of a larval herring population by jellyfish predator. Science 224:621-622

> Møller LF, Riisgård H (2007) Population dynamics, growth and predation impact of the common jellyfish Aurelia aurita and two hydromedusae, Sarsia tubulosa and Aequorea vitrina, in Limfjorden (Denmark). Mar Ecol Prog Ser 346:153-165

Myers RA, Worm B (2003) Rapid worldwide depletion of predatory fish communities. Nature 423:280-283

Myers RA, Worm B (2005) Extinction, survival or recovery of large predatory fishes. Proc R Soc Lond B Biol Sci 360: 13-20

Naumov DV (1969) Hydroids and hydromedusae of the USSR. Israel Program for Scientific Translation, Jerusalem

Niermann U (2004) Mnemiopsis leidyi: distribution and effect on the Black Sea ecosystem during the first year of invasion in comparison with other gelatinous blooms. In: 
Dumont HJ, Shiganova TA, Niermann U (eds) Aquatic invasions in the Black, Caspian and Mediterranean Sea. Nato Science Series IV, 35. Kluwer Academic, Dordrecht, p 3-31

Olesen NJ (1995) Clearance potential of jellyfish Aurelia aurita, and predation impact on zooplankton in a shallow cove. Mar Ecol Prog Ser 124:63-72

Pagès F (2001) Past and present anthropogenic factors promoting the invasion, colonization and dominance by jellyfish of a Spanish coastal lagoon. In: CIESM (ed) Gelatinous zooplankton outbreaks: theory and practice. CIESM Workshop Series 14, p 69-71

Pagliara P, Bouillon J, Boero F (2000) Photosynthetic planulae and planktonic hydroids: contrasting strategies of propagule survival. In: Mills CE, Boero F, Migotto A, Gili JM (eds) Trends in hydrozoan biology IV. Sci Mar 64:173-178

Parsons TR (1979) Some ecological, experimental and evolutionary aspects of the upwelling ecosystem. S Afr J Sci 75:536-540

Parsons TR (1988) Trophic phasing in theoretical, experimental and natural ecosystems. J Oceanogr Soc Japan 44: 94-101

Parsons TR, Lalli CM (2002) Jellyfish population explosions: Revisiting a hypothesis of possible causes. La Mer 40: 111-121

Pati AC, Belmonte G, Ceccherelli VU, Boero F (1999) The inactive temporary component: an unexplored fraction of meiobenthos. Mar Biol 134:419-427

Pauly D, Christensen VV, Dalsgaard J, Froese R, Torres F Jr (1998) Fishing down marine food webs. Science 279: 860-863

Perissinotto R, Pakhomov EA (1998) Contribution of salps to carbon flux of marginal ice zone of the Lazarev Sea, Southern Ocean. Mar Biol 131:25-32

Perissinotto R, Mayzaud P, Nichols PD, Labat JP (2007) Grazing by Pyrosoma atlanticum (Tunicata, Thaliacea) in the south Indian Ocean. Mar Ecol Prog Ser 330:1-11

Piraino S, Fanelli G, Boero F (2002) Variability of species' roles in marine communities: change of paradigms for conservation priorities. Mar Biol 140:1067-1074

Piraino S, De Vito D, Schmich J, Bouillon J, Boero F (2004) Reverse development in Cnidaria. Can J Zool 82:1748-1754

Purcell JE (1981) Feeding ecology of Rhyzophysa eysenhardti a siphonophore predator of fish larvae. Limnol Oceanogr 26:424-432

Purcell JE (1989) Predation of fish larvae and eggs by the hydromedusa Aequorea victoria at a herring spawning ground in British Columbia. Can J Fish Aquat Sci 46:1415-1427

Purcell JE (1997) Pelagic cnidarians and ctenophores as predators: selective predation, feeding rates and effects on prey populations. Ann Inst Oceanogr Paris (Nouv Ser) 73: 125-137

Purcell JE (2005) Climate effects on formation of jellyfish and ctenophore blooms: a review. J Mar Biol Assoc UK 85: 461-476

Purcell JE, Decker MB (2005) Effects of climate on relative predation by scyphomedusae and ctenophores on copepods in Chesapeake Bay during 1987-2000. Limnol Oceanogr 50:376-387

Purcell JE Graham WM, Dumont HJ (eds) (2001) Jellyfish blooms: ecological and societal importance. Developments in hydrobiology, No. 155. Kluwer Academic, Dordrecht

Purcell JE, Uye S, Lo W (2007) Anthropogenic causes of jellyfish blooms and their direct consequences for humans: a review. Mar Ecol Prog Ser 350:153-174

Ricci C (2001) Dormancy patterns in rotifers. Hydrobiologia 446-447:1-11

Riemann L, Titelman J, Båmstedt U (2006) Links between

Editorial responsibility: Otto Kinne,

Oldendorf/Luhe, Germany jellyfish and microbes in a jellyfish dominated fjord. Mar Ecol Prog Ser 325:29-42

Riisgård HU, Poulsen L, Larsen PS (1996) Phytoplankton reduction in near-bottom water caused by filter-feeding Nereis diversicolor-implications for worm growth and population grazing impact. Mar Ecol Prog Ser 141:47-54

Russell FS (1970) The medusae of the British Isles II. Pelagic scyphozoa with a supplement to the first volume on Hydromedusae. Cambridge University Press, London

Sanvicente-Añorve L, Soto LA, Espinosa-Fuentes ML, Flores-Coto C (2006) Relationship patterns between ichthyoplankton and zooplankton: a conceptual model. Hydrobiologia 559:11-22

Schmid V (1979) The use of an anthomedusa in establishing an in vitro regeneration system. Ann Soc Fr Biol Dev: 35-38

Schneider G, Behrends G (1994) Population dynamics and the trophic role of Aurelia aurita medusae in the Kiel Bight and western Baltic. ICES J Mar Sci 51:359-367

Sharrock D (2007) Salmon wiped out in attack by shoal of killer jellyfish. The TIMES ONLINE. Available at: www. timesonline.co.uk/tol/news/uk/science/article2917659.ece (accessed 22 Nov 2007)

Smetacek V (1985) Role of sinking in diatom life history cycles: ecological, evolutionary and geological significance. Mar Biol 84:239-251

Stearns SC (1992) The evolution of life histories. Oxford University Press, Oxford

Straehler-Pohl I, Jarms G (2005) Life cycle of Carybdea marsupialis Linnaeus, 1758 (Cubozoa, Carybdeidae) reveals metamorphosis to be a modified strobilation. Mar Biol 147:1271-1277

Tatsuki N (2005) Eutrophication and the increase of jellyfish population in the Seto Inland Sea. Bull Plankton Soc Jpn 52:27-31

Tilman D, Kilham SS, Kilham P (1982) Phytoplankton community ecology: the role of limiting nutrients. Annu Rev Ecol Syst 13:349-372

Titelman J, Hansson LH (2006) Feeding rates of the jellyfish of Aurelia aurita on fish larvae. Mar Biol 149:297-306

Uye S (1985) Resting egg production as life history strategy of marine planktonic copepods. Bull Mar Sci 37:440-449

Uye S, Ueta Y (2003) Recent increase of jellyfish in Hiroshima Bay based on the poll survey for fishermen. Bull Jpn Soc Fish Oceanogr 67:271-273

Uye S, Ueta Y (2004) Recent increase of jellyfish populations and their nuisance to fisheries in the Inland Sea of Japan. Bull Jpn Soc Fish Oceanogr 68:9-19

Valiela I (1995) Marine ecological processes (2nd edn). Springer-Verlag, New York

Verity PG, Smetacek V, Smayda TJ (2002) Status, trends and the future of the marine pelagic ecosystem. Environ Conserv 29:207-232

Volovik SP (ed) (2004) Ctenophore Mnemiopsis leidyi (A. Agassiz) in the Azov and Black Seas: its biology and consequences of its intrusions. Turkish Marine Research Foundation No. 17, Istanbul

Werner B (1954) On the development and reproduction of the anthomedusan, Margelopsis haeckeli Hartlaub. Trans N Y Acad Sci 16:143-146

Xian W, Kang B, Liu R (2005) Jellyfish blooms in the Yangtze estuary. Science 307:41

Yodzis P (2001) Must top predators be culled for the sake of fisheries? Trends Ecol Evol 16:78-84

Zeldis JR, Davis CS, James MR, Ballara SL, Booth WE, Chang FH (1995) Salp grazing effects on phytoplankton abundance, vertical distribution and taxonomic composition in a coastal habitat. Mar Ecol Prog Ser 126:267-283

Submitted: February 6, 2007; Accepted: December 13, 2007

Proofs received from author(s): February 27, 2008 